\title{
TINJAUAN YURIDIS ATAS GUGURNYA HAK UNTUK MENUNTUT PIDANA MENURUT UNDANG-UNDANG HUKUM PIDANA
}

Oleh : Nur Cahya Dian Saputra ${ }^{1}$ dan Syamsul Bahri ${ }^{2}$

${ }^{1}$ Fakultas Hukum Univesitas 17 Agustus 1945 Samarinda

${ }^{2}$ Dosen Fakultas Hukum Univesitas 17 Agustus 1945 Samarinda

\begin{abstract}
The violation of the right to sue is regulated in Chapter VII of the Criminal Code, while the violation of the right to sue is regulated in the Criminal Code, namely:

1. The principle of "Ne bis in idem" (Article 76 of the Criminal Code).

2. Death of the perpetrator (Article 77 of the Criminal Code).

3. Expiry (Article 78 of the Criminal Code).

4. Settlement of cases outside court trials (Article 82 of the Criminal Code).

5. Amnesty and Abolition from the President (Article 14 of the 1945 Constitution).

6. There are no complaints on complaints offenses.

This provision contained in the Criminal Code is to provide legal certainty for the community specifically the perpetrators of criminal acts. Provisions for the cancellation of the right to sue are the duties and functions of the Attorney General's Office of the Republic of Indonesia based on Law 16 of 2004.

The fall of the right to sue is caused by: 1) natural causes, 2) causes of human actions, and 3) legal causes It is hoped that the rules on the cancellation of the right to sue can be further emphasized in the new draft Law on Criminal Law (RKUHP) to provide legal certainty to the public. Likewise, cases of minor criminal acts (tipiring) should be resolved outside the court to avoid the accumulation of cases in court and the excess capacity of State Detention Centers or Penitentiaries.
\end{abstract}

Keywords: Judicial Review, Absence of Rights, Criminal Prosecution, Criminal Law

\footnotetext{
${ }^{1}$ Mahasiswa Fakultas Hukum Univesitas 17 Agustus 1945 Samarinda, Dalam Tulisan Ilmiah untuk mempoeroleh Gelar Sarjana Hukum (S1)

${ }^{2}$ Dosen Fakultas Hukum Univesitas 17 Agustus 1945 Samarinda.
} 


\begin{abstract}
ABSTRAK
Gugurnya hak untuk menuntut diatur dalam Bab VII KUHP, sedangkan gugurnya hak untuk menuntut diatur dalam KUHP, yakni :

1. Adanya asas "Ne bis in idem" (Pasal 76 KUHP).

2. Meninggalnya pelaku (Pasal 77 KUHP).

3. Daluwarsa (Pasal 78 KUHP).

4. Penyelesaian perkara di luar sidang pengadilan (Pasal 82 KUHP).

5. Amnesti dan Abolisi dari Presiden (Pasal 14 UUD 1945).

6. Tidak adanya pengaduan pada delik-delik aduan.

Ketentuan ini dimuat dalam KUHP adalah untuk memberikan kepastian hukum bagi masyarakat khusus pelaku tindak pidana. Ketentuan gugurnya hak menuntut adalah merupakan tugas dan fungsi Kejaksaan Republik Indonesia berdasarkan Undang-Undang 16 Tahun 2004.

Gugurnya hak untuk menuntut disebabkan :1) Sebab alamiah;2) sebab perbuatan manusia; dan 3) sebab hukum.

Diharapkan aturan gugurnya hak untuk menuntut dapat lebih dipertegas dalam rancangan Undang-undang Hukum Pidana (RKUHP) yang baru untuk memberikan kepastian hukum kepada masyarakat. Demikian juga terhadap perkara-perkara tindak pidana ringan (tipiring) sebaiknya dapat diselesaikan di luar pengadilan untuk menghindari bertumpuknya perkara di pengadilan dan kelebihan kapisitas Rumah Tahanan Negara atau Lembaga Pemasyarakatan.
\end{abstract}

\title{
Kata Kunci : Tinjauan Yuridis, Gugurnya Hak, Menuntut Pidana, Undang-Undang Hukum Pidana
}




\section{PENDAHULUAN}

\section{A. Latar Belakang}

Hapusnya kewenangan menuntut pidana dan menjalankan pidana, telah diatur sedemikian rupa tentang gugur hak untuk menunut pidana sebelum perkara pidana materiil dijalankan guna memperjelas semua ketentuan-ketentuan pelaksanaan pidana meteriil yang terdapat pada Buku II tentang Kejahatan dan Buku III tentang Pelanggaran. Pembuat ketentuan pidana dalam KUHP memberikan pengaturan-pengaturan mengenai : Gugurnya hak untuk menuntut dan menjalani hukuman oleh pelaku pidana dapat disebabkan beberapa hal antara lain : Adanya asas "Ne bis in idem" Meninggalnya pelaku, Daluwarsa, Penyelesaian perkara di luar sidang pengadilan, Amnesti dan Abolisi dari Presiden dan Tidak adanya pengaduan pada delik-delik aduan. ${ }^{3}$

Berkenaan dengan "ne bis in idem" diatur Pasal 76 ayat (1) KUHP menyatakan : "Kecuali dalam hal putusan hakim masih mungkin diulangi, orang tidak boleh dituntut dua kali karena perbuatan yang oleh hakim Indonesia terhadap dirinya telah diadili dengan putusan menjadi tetap".

Maksud dari asas" Ne bis in idem" tersebut adalah dalam hal adanya suatu perkara yang telah diajukan dan telah mendapat keputusan yang pasti dan tetap dari pengadilan, tidak dapat diajukan untuk kedua kalinya dalam hal yang sama, atau dengan kata lain "Tidak seorangpun atas perbuatannya dapat dituntut untuk kedua kalinya " (Nemmo debet bis vexari).

Alasan gugurnya hak untuk menuntut lainnya yakni : Penyelesaian perkara di luar sidang pengadilan sebagaimana diatur Pasal 82 KUHP, yakni : Dalam hal terjadi pelanggaran yang diancam denda yaitu membayar kepada kejaksaan maksimum denda yang dikeluarkan untuk perkara, maka si pelaku harus membayar denda dan biaya perkara tersebut dan kalau tidak maka ia bisa dikenakan pidana kurungan sebagai pengganti denda dan biaya perkara tersebut.

Hal lain yang gugurnya hak untuk menuntut oleh karena penyelesaian perkara di luar Pengadilan berupa mediasi penal, penyelesaian perkara-perkara yang bersifat delik aduan, disepakati kedua belah pihak dan tidak saling menuntut dikemudian hari, hal ini diatur dalam Peraturan Mahkamah Agung Nomor 1 Tahun 2008.

\footnotetext{
${ }^{3}$ https://butew.com/2018/04/10/sebab-sebab-gugurnya-hak-untuk-menuntut-danmenjalani-hukuman-pidana/
} 


\section{B. Perumusan dan Pembatasan Masalah}

1. Apa saja bentuk-bentuk gugurnya hak untuk menuntut yang diatur dalam Kitab Undang-Undang Hukum Pidana (KUHP)?.

2. Apa saja sebab-sebab gugurnya hak untuk menuntut yang diatur dalam Kitab Undang-Undang Hukum Pidana (KUHP) ?.

\section{Tujuan Penelitian}

1. Untuk mengetahui bentuk-bentuk gugurnya hak untuk menuntut yang diatur dalam Kitab Undang-Undang Hukum Pidana (KUHP) ?.

2. Untuk mengetahui sebab-sebab gugurnya hak untuk menutut yang diatur dalam Kitab Undang-Undang Hukum Pidana (KUHP) ?.

\section{KERANGKA DASAR TEORI}

\section{A. Pengertian Tindak Pidana}

Para pakar asing Hukum Pidana menggunakan istilah Tindak Pidana atau Perbuatan Pidana atau Peristiwa Pidana dengan istilah: ${ }^{4}$

a. Strafbaar Feit adalah peristiwa pidana, ${ }^{5}$ Istilah ini pertama kali dikemukakan oleh Wirjono Prodjodikoro, dalam perundang-undangan formal Indonesia, istilah "peristiwa pidana" pernah digunakan secara resmi dalam UUD Sementara 1950, yaitu dalam Pasal 14 ayat (1). Secara substansif, pengertian dari istilah "peristiwa pidana" lebih menunjuk kepada suatu kejadian yang dapat ditimbulkan baik oleh perbuatan manusia maupun oleh gejala alam. Oleh karena itu, dalam percakapan sehari-hari sering didengar suatu ungkapan bahwa kejadian itu merupakan peristiwa alam. ${ }^{6}$

b. Strafbare Handlung diterjemahkan dengan Perbuatan Pidana, yang digunakan oleh para sarjana Hukum Pidana Jerman. ${ }^{7}$ Mulyatno, menerjemahkan istilah strafbaar feit dengan perbuatan pidana. Menurut pendapat beliau istilah "perbuatan pidana" menunjuk kepada makna adanya suatu kelakukan manusia yang menimbulkan akibat tertentu yang dilarang hukum di mana pelakunya dapat dikenakan sanksi pidana. Dapat diartikan demikian karena kata "perbuatan" tidak mungkin berupa kelakuan alam, karena yang dapat berbuat dan hasilnya disebut perbuatan itu adalah hanya manusia.

c. Criminal Act diterjemahkan dengan istilah Perbuatan Kriminal. Delik yang dalam bahasa Belanda disebut Strafbaarfeit, terdiri atas tiga kata,

\footnotetext{
4 Amir Ilyas, 2012, Asas-asas Hukum Pidana, Rangkang Education, Yogyakarta, hlm.18.

${ }^{5}$ Ibid., hlm 19

${ }^{6}$ Teguh Prasetyo,2012, Hukum Pidana, PT. RajaGrafindo Persada, Jakarta. Hlm 49

${ }^{7}$ Amir Ilyas, loc.cit
} 
yaitu straf, baar, dan feit. Yang masing-masing memiliki arti yaitu Strafdiartikan sebagai pidana dan hukum, Baar diartikan sebagai dapat dan boleh, dan Feit diartikan sebagai tindak, peristiwa, pelanggaran dan perbuatan.

Oleh karena itu, setelah melihat berbagai definisi di atas, maka dapat diambil kesimpulan bahwa yang disebut dengan tindak pidana adalah perbuatan yang oleh aturan hukum dilarang dan diancam dengan pidana, dimana pengertian perbuatan disini selain perbuatan yang bersifat aktif (melakukan sesuatu yang sebenarnya dilarang oleh hukum) hukum juga perbuatan yang bersifat pasif (tidak berbuat sesuatu yang sebenarnya diharuskan oleh hukum).

\section{B. Teori Tujuan Pemidanaan}

Sehubungan dengan tujuan pemidanaan, terdapat 3 (tiga) teori untuk membenarkan penjatuhan pidana :

1. Teori absolute atau pembalasan.

Tokoh-tokohnya antara lain Kant, Hegel, Krannenburg, Polak. Menurut Kant, setiap orang yang melakukan kejahatan harus dipidana berdasarkan asas pembalasan. Tujuan yang membenarkan dapat dijatuhkannya pidana adalah keadilan. ${ }^{8}$

Menurut Hegel, bahwa kejahatan yakni sebagai pengingkaran hukum, oleh karena itu setiap kejahatan yang diperbuat harus ada keseimbangan nilai. Menurut Kraenburg, bahwa kesadaran hukum mengharuskan si penjahat merasakan apa yang telah diperbuatnya terhadap masyarakat. Menurut Polak bahwa setiap kejahatan mengandung pencelaan yang objektif.

Dari uraian di atas dapat disimpulkan, bahwa teori pembalasan penjatuhan pidana bertitik pangkal pada pembalasan yang diberikan oleh Negara kepada pelaku kejahatan.Siapa saja yang berbuat jahat harus dibalas dengan memberikan pidana. Tidak melihat akibat-akibat apa saja yang dapat timbul karena dijatuhkan pidana. Yang dilihat hanya masa lalu, tidak dilihat masa yang akan datang terpidana. Tujuan menjatuhkan pidana untuk menjadikan si penjahat menderita. ${ }^{9}$

2. Teori Relative atau Nisbi.

Tokoh-tokoh teori ini diantaranya Fichte, Bauer, Grollman. Menurut Fichte, bahwa pidana merupakan alat untuk mencapai salah satu tujuan Negara dalam rangka menjamin ketertiban umum. tujuan pidana yaitu untuk menakuti si penjahat dan masyarakat untuk tidak melakukan kejahatan. Menurut Bauer, bahwa ancaman pidana

\footnotetext{
${ }^{8}$ Widodo, 2009, Sistem PemidanaanDdalam Cyber Crime, Laksbang, Yogyakarta, hal.71

${ }^{9}$ Loc cit, hlm, 31-32.
} 
ditujukan terhadap sifat kesusilaan manusia. Menurut Grollman, bahwa tujuan pidana adalah untuk menakuti si penjahat agar tidak melakukan kejahatan lagi.

Beberapa point tentang teori ini :

1) Teori ini bertitik pangkal bahwa pada dasarnya pidana adalah alat untuk menegakan tata tertib dalam masyarakat.

2) Kejahatan tidak hanya diikuti dengan suatu pidana saja namun dipersoalkan tentang manfaat pidana tersebut bagi masyarakat dan bagi si penjahat itu sendiri.

3) Teori ini tidak hanya melihat pada masa lampau tapi juga melihat masa depan terpidana.

4) Tujuan pidana diarahkan kepada usaha agar kejahatan yang diperbuat oleh sipenjahat tidak terulang lagi.

3. Teori gabungan.

Teori ini mendasarkan pidana atas asas pembalasan dan asas pertahanan tata tertib hukum masyarakat. Teori ini dibagi menjadi 3 (tiga) golongan $:^{10}$

(1) Teori gabungan yang menitikberatkan pada pembalasan, tetapi pembalasan tersebut tidak boleh melampaui batas dan cukup untuk dapat mempertahankan tata tertib.

(2) Teori gabungan yang menitikberatkan pada pertahanan tata tertib masyarakat. Menurut teori ini penjatuhan pidana bertujuan untuk mempertahankan tata tertib masyarakat, namun penderitaan atas pidana yang dijatuhkan tidak boleh lebih berat dari pada perbuatan yang dilakukan oleh terpidana.

(3) Teori gabungan yang menganggap bahwa pidana memenuhi keharusan pembalasan dan keharusan melindungi masyarakat.

Teori gabungan inilah yang paling tepat digunakan oleh Polresta Samarinda dalam upaya pemberantasan tindak pidana narkotika di wilayah hukum Polresta Samarinda, tuntutan pidana yang diterapkan oleh Penuntut Umum bukan lah sebagai semata-mata hanya sebagai efek jera bagi pelaku kejahatan narkotika, namun lebih dari pada itu tuntutan yang diberikan haruslah lebih sebagai pembinaan agar nantinya pelaku kejahatan dapat dibina dan kembali di tengah masyarakat dengan perilaku yang baik. Sehingga di sinilah pentingnya kejelian Penuntut Umum dalam melakukan penuntutan pada saat persidangan dengan mempertimbangkan fakta-fakta persidangan disertai dengan barang bukti yang ada, Penuntut Umum haruslah mengedepankan keadilan serta hati nurani sehingga tuntutan yang diberikan kepada pelaku kejahatan dapat benar-benar dirasakan adil tidak hanya bagi pelaku

\footnotetext{
${ }^{10}$ Ibid, hlm. 33 .
} 
kejahatan itu sendiri namun juga masyarakat demi terciptanya keamaan dan ketertiban dalam kehidupan masyarakat.

\section{Teori Pertanggungjawaban}

Di dalam teori hukum dikenal pengertian tanggung jawab, pertama ialah pertanggungjawaban dalam arti sempit, yaitu tanggung jawab tanpa sanksi.Yang kedua ialah tanggung jawab dalam arti luas, yaitu tanggungj awab dengan sanksi. ${ }^{11}$

Webster Dictionary memformulasikan pengertian accountability sebagai: the state of being accountable, responsible, or liable, accountableness. $^{12}$

Accountability mengandung pengertian dapat dipertanggungjawabkan, bertanggungjawab, atau dapat dikenakan tanggungjawab, tidak dapat dipertanggungjawabakan.

Dapat dipertanggungjawabkan:

1. Dapat dikenakan untuk diminta tanggung jawab: dapat menjawab kepada atasan, sebab semua orang adalah dapat dipertanggungjawabkan kepada tuhan atas tindakannya,

2. Mampu untuk diminta dipertanggungjawabkan secara tegas atau eksplisit,

3. Yang mungkin dihitung atau untuk dihitung. adalah: ${ }^{13}$

Selanjutnya Kohler's Dictionary of accountant, accountability

1. Kewajiban pegawai, agen, atau orang lain untuk menyediakan laporan yang memuaskan, secara berkala, tentang tindakan atau tindakan failure to yang diikuti pemberian wewenang,

2. Kemudian (akuntansi pemerintah) tujuan dari tanggung jawab atau pembayaran sejumlah kewajiban petugas,

3. Ukuran tanggung jawab atau kewajiban lain, dalam bentuk uang, unit kepemilikan, atau bentuk lainnya,

4. Kewajiban membuktikan manajemen yang baik, pengontrolan, atau hasil lainnya dihadapkan kemuka hukum, peraturan, persetujuan, atau kebiasaan.

Sementara responsibility di dalam Kohler's Dictionary for Accountant diartikan sebagai kewenangan yang dianggap sebagai kewajiban untuk melaksanakan secara hati-hati dalam melaksanakan tugas

11 Ismail Sunny, 2000, Mekanisme Demokrasi Pancasila, Varuna, Jakarta, hlm 18

${ }^{12}$ M.C. Kenchnie, Jean L, 1983, Webster New Universal Unabridged Dictionary, Second Edicition Simon Schulster, hlm 13

${ }^{13}$ Cooper, W.W, Yuji, Kohler, 1984, Dictionary for Accountant, Prentice Hall of India, New Delhi, hlm 7 
atau kewenangan yang melekatan pada individu atau kelompok dalam rangka mengambil keputusan atau kegiatan organisasi. ${ }^{14}$

Terlepas dari perbedaan pendapat itu, ada dua macam pertanggungjawaban, yaitu:

1. Pertanggungjawaban moral (moral responsibility), dan

2. Pertanggungjawaban politik.

Pertanggungjawaban moral adalah pertanggungjawaban yang tidak menuntut sanksi yuridis, karena pentaatanya tidak dipaksakan dari luar (secara heteronom), tetapi pentaatannya otonom dari dalam nurani pejabat atau penguasa yang berwenang itu sendiri. Dibalik itu pertanggungjawaban politik adalah pertanggungjawaban yang menimbulkan akibat dapat dijatuhkannya sanksi politik berupa pemecatan dari jabatan pejabat atau penguasa yang berwenang dari jabatannya sebelum masa jabatannya berakhir (impeachment).Meskipun dalam pertanggungjawaban moral tidak mengakibatkan dapat dijatuhkannya sanksi yuridis, tetapi dalam mengimplementasikan hukum positif, badan atau lembaga Negara tidak dibenarkan mengabaikan asas-asas moral. ${ }^{15}$

Pertanggungjawaban kepada rakyat dapat dilakukan dengan dua cara yaitu melalui wakil rakyat atau langsung kepada rakyat. Sistem pertanggungjawaban melalui wakil rakyat (parlemen) melahirkan sistem pemerintahan parlementer.Pertanggungjawaban langsung kepada rakyat melahirkan sistem presidensiil.Sistem pemerintahan perlementer dapat berjalan pada bentuk pemerintahan kerajaan atau republik.Tidak demikian dengan sistem pemerintahan presidensiil yang hanya terdapat pada bentuk pemerintahan republik, yaitu pertanggung jawaban presiden sebagai penyelenggara pemerintahan.

\section{Pengertian Penyidikan dan Penuntutan}

Pengertian penyidikan secara umum dalam KUHAP dijelaskan dalam Bab I Pasal 1 angka 2 yang berbunyi:

"Penyidikan adalah serangkaian tindakan penyidik dalam hal dan menurut cara yang diatur dalam undang-undang ini untuk mencari serta mengumpulkan bukti yang dengan bukti itu membuat terang tentang tindak pidana yang terjadi dan guna menemukan tersangkanya".

Hal ini untuk mengambarkan :

"pengertian kata penyidikan, KUHAP membedakan penyidikan dan penyelidikan. Penyidikan sejajar dengan pengertian opsporing atau investigation. Pembedaan kedua istilah tersebut rupanya tidak

\footnotetext{
${ }^{14}$ Ibid, hlm 435

15 Lukman Hakim, Op. Cit, hlm 45
} 
didasarkan kepada pengertian biasa. Pengertian biasa menunjukkan bahwa penyidikan berasal dari kata sidik yang mendapat sisipan el, menjadi selidik. Artinya sama dengan sidik, hanya diperkeras pengertiannya, banyak". ${ }^{16}$

Sejalan dengan ketentuan di atas dalam penyidikan tindak pidana korupsi selain dari Kepolisian, Kejaksaan sebagai pejabat pegawai negeri sipil juga mempunyai wewenang untuk menjadi penyidik dan melakukan penyidikan. Apabila penyidikan dilakukan oleh penyidik Kejaksaan, maka sejak laporan/pengaduan diterima pihak kejaksaan wajib memberitahukannya kepada penyidik Polri tentang proses penyidikannya dan segala hal yang berkaitan dengan itu. Apabila penyidikan telah selesai, maka Kejaksaan segera menyampaikan laporan beserta berita acara pemeriksaan kepada penyidik Polri. Kewenangan ini berdasarkan UndangUndang Nomor 16 Tahun 2004 tentang Kejaksaan Republik Indonesia. Pasal 2 ayat (1) Undang-Undang 16 Tahun 2004 menyatakan :

"Kejaksaan Republik Indonesia yang selanjutnya dalam UndangUndang ini disebut kejaksaan adalah lembaga pemerintah yang melaksanakan kekuasaan negara di bidang penuntutan serta kewenangan lain berdasarkan undang-undang”.

Kejaksaan Republik Indonesia memilik tugas dan wewenang sebagai Penuntut Umum sebagaimana disebutkan pada Pasal 2 ayat (1) di atas, akan tetapi dapat melaksanakan kewenangan lain berdasarkan Pasal 30 ayat (1) huruf d yang menyatakan :

"di bidang pidana kejaksaan mempunyai tugas dan wewenang melakukan penyidikan terhadap tindak pidana tertentu berdasarkan undang-undang".

Penuntutan suatu perkara dapat dilakukan dengan berbagai cara. Cara tersebut bergantung pada berat ringannya suatu perkara. Jika perkara itu termasuk perkara biasa yang ancaman pidananya di atas satu tahun maka penuntutannya dilakukan dengan cara biasa, hal ini ditandai dengan adanya berkas perkara yang lengkap dan rumit. Ciri utama dalam penuntutan ini adalah selalu disertai dengan surat dakwaan yang disusun secara cermat dan lengkap oleh penuntut umum. Selain penuntutan dengan cara biasa tersebut, penuntutan dapat pula dilakukan dengan cara singkat. Penuntutan ini dilakukan jika perkaranya diancam pidana lebih ringan, yakni tidak lebih dari satu tahun penjara. Berkas perkara biasanya tidak rumit, dan penuntut umum tetap mengajukan surat dakwaan yang disusun

\footnotetext{
${ }^{16}$ Hamzah, Andi, 2000, Hukum Acara Pidana Indonesia, PT. Sinar Grafika, Jakarta, hlm 118
} 
secara sederhana. Jenis penuntutan lainnya adalah penuntutan dengan cara cepat. Penuntutan jenis ini terjadi pada perkara yang ringan atau perkara lalu lintas yang ancaman hukumannya tidak lebih dari tiga bulan. Penuntutan tidak dilakukan oleh penuntut umum, namun diwakili oleh penyidik dari polisi. Dalam hal ini juga tidak ada surat dakwaan tetapi hanya berupa catatan kejahatan atau pelanggaran yang dilakukan. Selanjutnya Pasal 141 KUHAP menentukan bahwa penuntutan dapat dilakukan dengan menggabungkan perkara dengan satu surat dakwaan. Tetapi kemungkinan penggabungan itu dibatasi dengan syarat-syarat oleh pasal tersebut. Syarat-syarat itu adalah : "a. Beberapa tindak pidana yang dilakukan oleh seorang yang sama dan kepentingan pemeriksaan tidak menjadikan halangan terhadap penggabungannya; b. Beberapa tindak pidana yang bersangkut-paut satu dengan yang lain; c. Beberapa tindak pidana yang tidak bersangkut-paut satu dengan yang lain, akan tetapi satu dengan yang lain itu ada hubungannya, yang dalam hal ini penggabungan tersebut perlu bagi kepentingan pemeriksaan".

\section{HASIL PENELITIAN DAN PEMBAHASAN}

\section{A. Bentuk-Bentuk Gugurnya Hak untuk Menuntut yang Diatur dalam Kitab Undang-Undang Hukum Pidana (KUHP)}

Kitab Undang-Undang Hukum Pidana yang lazim kita sebut KUHP adalah kumpulan aturan hukum pidana umum (recht public) yang berisikan pidana materiil (crimnial material), KUHP terdiri dari Buku I yang berisikan tentang ketentuan umum, buku II tentang kejahatan dan buku III beisikan tentang pelanggaran. Berkenaan dengan Hapusnya Kewenangan Menuntut Pidana dan Menjalankan Pidana diataur dalam buku I, Bab VII.

Menurut hemat Penulis ketentuan-ketentuan gugurnya hak untuk menuntut yang diuraikan di atas adalah "semi pidana formil" karena pengaturan tentang penuntutan diatur di dalam Undang-Undang Nomor 8 Tahun 1981tentang Kitab Undang Undang Hukum Acara Pidana (KUHAP), akan tetapi ketentuan gugurnya hak untuk menuntut diatur dalam buku I ini adalah merupakan pemberian batasan umum bagi penegak hukum khususnya Penuntut Umum dalam menerapkan KUHP, bahwasanya tidak semua perkara tindak pidana dapat dituntut ke hadapan pengadilan.

Ketentuan-Ketentuan atau bentuk-bentuk gugurnya hak untuk menuntut berkaitan dengan asas-asas pidana, dokrin-dokrin dan ketentuanketentuan pidana yang sudah ditentukan pada pasal-pasal awal dalam KUHP, seperti asas legalitas sebagaimana diatur dalam Pasal 1 ayat (1) KUHP, asas memilih yang menguntungkan bagi terdakwa bilamana terjadi 
perubahan perundang-undangan, waktu terjadinya tindak pidana dan ajaran-ajaran mengenai delik pidana.

Penerapan ketentuan gugurnya hak menuntut oleh Penuntut Umum, penuntut umum harus mengerti kaidah-kaidah hukum yang ditentukan di atas, baik itu asas-asas hukum, doktrin atau ajaran-jaran hukum, sehingga penuntut umum tidak keliru memaknai gugur hak untuk menuntut.

Bentuk-bentuk gugurnya hak untuk menuntut seperti Penulis uraikan di atas implementasinya ada pada Jaksa Penuntut Umum karena tugas dan fungsi Kejaksaan adalah salah satunya melukan penuntutan, yang dtuntut adalah terdakwa pelaku tindak pidana dihadap pengadilan.

Pengaturan gugurnya hak untuk menuntut sebagaimana diatir dalam KUHP, yaitu :

\section{Adanya asas "Ne bis in idem" (Pasal 76 KUHP).}

Pasal 76 ayat (1) KUHP menyatakan :

"Kecuali dalam hal putusan hakim masih mungkin diulangi, orang tidak boleh dituntut dua kali karena perbuatan yang oleh hakim Indonesia terhadap dirinya telah diadili dengan putusan menjadi tetap".

Selanjutnya dalam artian hakim Indonesia, termasuk juga hakim swapraja dan adat, ditempat-tempat yang mempunyai pengadilan-pengadilan tersebut. Pasal 76 ayat (2) KUHP jika putusan menjadi tetap itu berasal dari hakim lain, maka terhadap orang itu dan karena tindak pidana itu pula, tidak boleh diadakan penuntutan dalam hal :

1. Putusan berupa pembebasan dari tuduhan atau lepas dan tuntutan hukum;

2. Putusan berupa pemidanaan dan telah dijalani seluruhnya atau telah diberi ampun atau wewenang untuk menjalankannya telah hapus karena daluarsa.

Maksud dari asas" Ne bis in idem" tersebut adalah dalam hal adanya suatu perkara yang telah diajukan dan telah mendapat keputusan yang pasti dan tetap dari pengadilan, tidak dapat diajukan untuk kedua kalinya dalam hal yang sama, atau dengan kata lain "Tidak seorangpun atas perbuatannya dapat dituntut untuk kedua kalinya " (Nemmo debet bis vexari).

Perkara yang telah mendapat keputusan yang pasti tidak dapat dituntut kembali untuk kedua kalinya, dengan syarat-syarat yaitu :

1. Sama pelakunya.

2. Sama perbuatannya.

3. Atas perbuatan tersebut telah ada vonis (putusan) dari hakim pengadilan yang pasti dan tetap. 
Alasan dari asas atau prinsip tersebut adalah untuk kepentingan masyarakat akan suatu kepastian hukum dan ketentraman dalam hidupnya serta untuk menjaga martabat pengadilan dan untuk rasa kepastian bagi terdakwa yang telah mendapat putusan.

Pengecualiannya:

1. Untuk peninjauan kembali (Herziening) perkara karena terdapat kesalahan dalam vonisnya.

2. Kasasi demi kepentingan umum.

\section{Meninggalnya Pelaku (Pasal 77 KUHP)}

Pasal 77 KUHP menegaskan : "Kewenangan menuntut pidana hapus, jika tertuduh meninggal dunia". Secara yuridis dengan meninggalnya si pelaku tindak pidana, karena kesalahan seseorang itu bersifat pribadi maka kesalahannya tidak dapat dilimpahkan pada orang lain untuk memikul kesalahan si pelaku tindak pidana.

Apabila pelaku tindak pidana meninggal dunia maka :

a. Bila seorang terdakwa meninggal dunia sebelum ada putusan pengadilan, maka perkara pidana tersebut menjadi gugur.

b. Bila perkara pidana tersebut masih dalam proses penyidikan, maka perkaranya dihentikan.

c. Jika penuntutan telah diajukan oleh Jaksa penuntut umum dan si terdakwa meninggal sebelum mendapat putusan pengadilan, maka oleh pengadilan perkara pidana tersebut harus dinyatakan tidak dapat diterima.

Pengecualiannya bahwa dengan meninggalnya si pelaku "tidak mutlak" menjadi gugur, yaitu terhadap barang-barang atau hak-hak yang dimiliki, dan biasanya diterapkan terhadap hukuman denda atau tuntutan tambahan tetap dijalankan.

Apabila dalam proses penyidikan (Polisi), tersangka meninggal dunia, maka penyidikan tersebut dihentikan, kemudian apabila terdakwa pada masa penuntutan meninggal dunia, maka harus dikeluarkan surat penetapan dari hakim pengadilan negeri.

Penghentian penyidikan diatur Pasal 109 ayat (2) Kitab Undang-Undang Hukum Acara Pidana (KUHAP), yaitu :

"Dalam hal penyidik menghentikan penyidikannya karena tidak mendapat cukup bukti atau peristiwa tersebut bukan merupakan tindak pidana atau penyidikan dihentikan demi hukum, maka penyidik memberitahukan hal itu kepada pentuntut umum, tersangka atau keluarganya". 
Penghentian penyidikan secara teknis diatur dalam Peraturan Kepala Kepolisian Republik Indonesia Nomor 6 Tahun 2019, tentang Penyidikan Tindak Pidana. Pasal 30 ayat (1) menyebutkan :

“(1) Penghentian penyidikan dilakukan melalui Gelar Perkara.

(2) Penghentian penyidikan dapat dilakukan untuk memenuhi kepastian hukum, rasa keadilan dan kemanfaatan hukum. (3) Penghentian penyidikan dilaksanakan sesuai dengan ketentuan peraturan perundang-undangan"

Surat Perintah Penghentian Penyidikan, lazin dikenal dengan SP3, merupakan surat pemberitahuan dari penyidik ke penuntutm umum bahwa perkara dihentikan oleh penyidiknya. SP3 menggunakan formulir yang telah ditentukan dalam Keputusan Jaksa Agung No. 518/A/J.A/11/2001 tanggal 1 November 2001 tentang perubahan Keputusan Jaksa Agung Republik Indonesia No. 132/JA/11/1994 tentang Admistrasi Perkara Tindak Pidana. Adalah sifatnya administasi penanganan suatu perkara.

Memperhatikan ketentuan-ketentuan di atas adalah semata diurakan tentang penghentian penyidikan berkenaan dengan penyidik tidak mendapat cukup bukti atau peristiwa tersebut bukan merupakan tindak pidana atau penyidikan dihentikan demi hukum. bila memaknai ketentuan Pasal 109 ayat (2) KUHAP dan Pasal 30 ayat (1) Peraturan Kepala Kepolisian Republik Indonesia Nomor 6 Tahun 2019, tentang Penyidikan Tindak Pidana, keduanya tidak mengeaskan penghentian penyidikan oleh karena tersangka meninggal dunia. Hanya dapat dimaknai pada frasa "penyidikan dihentikan demi hukum".

\section{Daluwarsa (Pasal 78 KUHP)}

Kewenangan menuntut pidana hapus karena daluarsa :

1) Mengenai semua pelanggaran dan kejahatan yang dilakukan dengan percetakan sesudah satu Tahun;

2) Mengenai kejahatan yang diancam dengan pidana denda, pidana kurungan atau pidana penjara paling lama tiga Tahun, sesudah 6 Tahun.

3) Mengenai kejahatan yang diancam dengan pidana penjara lebih dari tiga Tahun, sudah dua belas Tahun;

4) Mengenai kejahatan yang diancam pidana mati atau pidana penajara seumur hidup, sesudah delapan belas Tahun.I

5) Bagi orang yang pada saat melakukan perbuatan umurnya belum delapan belas Tahun, masing-masing tenggang daluarsanya di atas dikurangi menjadi sepertiga.

Adapun alasan-alasan daluarsa yang diatur dalam KUHP, yaitu: 
1) Apabila suatu perbuatan pidana oleh karena beberapa hal diselidiki dalam waktu yang lama, maka masyarakat sudah tidak ingat lagi sehingga tidak begitu dirasakan manfaatnya.

2) Lebih lama pengusutan, maka sukar mendapat bukti-bukti yang cukup apabila terdakwa memungkiri.

\section{Tabel 1. Perbandingan Daluasa antara Pasal 78 KUHP dengan Pasal 82 ayat (2) KUHP}

\begin{tabular}{|c|c|c|}
\hline $\begin{array}{l}\text { Pengkulifikasian Jenis Tindak Pidana } \\
\text { dengan ancaman sanksi }\end{array}$ & $\begin{array}{c}\text { Pasal } 78 \\
\text { KUHP }\end{array}$ & $\begin{array}{l}\text { Pasal } 82 \text { ayat (2) } \\
\text { KUHP } \\
\end{array}$ \\
\hline $\begin{array}{l}\text { Pelanggaran Kejahatan dengan alat } \\
\text { cetak }\end{array}$ & 1 tahun & 5 tahun \\
\hline \multirow{2}{*}{$\begin{array}{l}\text { Denda kurungan atau penjara kurang } 3 \\
\text { tahun }\end{array}$} & \multirow[t]{2}{*}{6 tahun } & 2 tahun \\
\hline & & 8 tahun \\
\hline Penjara lebih 3 tahun & 12 tahun & 16 tahun \\
\hline Pidana penjara seumur hidup & \multirow[t]{2}{*}{18 tahun } & $\begin{array}{l}\text { Dlm hal ini tidak ditentukan } \\
\text { tetapi metunjuk pada asas } \\
\text { bahwa lamanya tindak pidana } \\
\text { tidak boleh lebih singkat dari } \\
\text { masa pemidanaan itu sendiri. } \\
\text { Maka tidak ada daluarsa untuk } \\
\text { klasikasi ini. }\end{array}$ \\
\hline Pidana mati & & Tidak ada masa daluarsa \\
\hline
\end{tabular}

Menjadi masalah berkaitan dengan daluarsa pemidanaan bagi anak adalah dalam KUHP dan Undang-Undang Pidana Nomor 3 Tahun 1997 tidak dinyatakan dengan tegas tentang permasalah dengan pidana anak. Berdasarkan ketentuan dalam pasal 82 KUHP yang merujuk kepada ketentuan Pasal 78 KUHP, maka ketentuan mengenai daluarsa pemidanaan anak pun menjadi masalah. Bila ketentuan Pasal78 ayat (2) dimana masa tempodaluarsa penuntutan dikurangi hingga menjadi $1 / 3$ nya, maka masa tempo daluarsa pemidanaan harus juga mengikuti ketentuan tersebut. 


\title{
Kolom.1
}

Gambaran dari perhitungan perhitungan daluarsa :

\begin{abstract}
si X (13 tahun) berkelahi dengan temannya dan menyebabkan temannya terluka. Atas tindakan tersebut, hakim menjatuhkan pidana 1 tahun 6 bulan penjara atas dasar Pasal 351 ayat (1) KUHP. Namun si X berhasil melarikan diri saat dirinya baru saja tiba di Lembaga Pemasyarakatan. Dalam hal ini, tempo masa daluarsa pemidanaan bagi perkara $\mathrm{X}$ adalah :

Dalam Pasal 351 ayat (1) KUHP, ancaman pidananya adalah 2 tahun 8 bulan, berarti dalam pasal 78 tentang perhitungan daluarsa penutntan, dimasukkan dalam kualifikasi tindak pidana yang ancamannya di bawah 3 tahun, tempo daluarsanya 6 tahun. Dalam Pasal 92 ayat (2), masa daluarsa pemidanaan ditambah 1/3/ dari masa daluarsa penuntutan.

$$
6+1 / 3(6)=8 \text { tahun }
$$
\end{abstract}

Karena si $\mathrm{X}$ adalah anak yang baru berusia 13 tahun, maka masa daluarsanya adalah $1 / 3$ dari 8 tahun yaitu 2 tahun 8 bulan.

Berdasarkan asas bahwa tempo daluarsa pemidanaan tidak boleh lebih singkat dari masa pemidanaan itu sendiri, menurut hemat Penulis perhitungan ini menjadi logis. Dan bila pandangan tersebut diterima, maka tempo daluarsa pemidanaan bagi seorang anak pelaku tindak pidana adalah sebagai berikut :

Tabel 2. Masa daluarsa pemidanaan tidak boleh lebih singkat dari masa pemidanaan pokok

\begin{tabular}{|c|c|c|c|}
\hline $\begin{array}{c}\text { Pengkualisfikasian Jenis } \\
\text { Tindak Pidana dengan } \\
\text { ancaman sanksi }\end{array}$ & $\begin{array}{c}\text { Pasal } 78 \\
\text { KUHP }\end{array}$ & $\begin{array}{c}\text { Pasal } 82 \text { ayat (2) } \\
\text { KUHP }\end{array}$ & Anak \\
\hline $\begin{array}{l}\text { Pelanggarankejahatan } \\
\text { dengan alat cetak }\end{array}$ & 1 tahun & 5 tahun & 1 tahun 8 bulan \\
\hline \multirow{2}{*}{$\begin{array}{lc}\text { Denda, } & \text { kurungan atau } \\
\text { penjara } & \text { sekurang- } \\
\text { kurangnya dari } 3 \text { tahun }\end{array}$} & \multirow[t]{2}{*}{6 tahun } & 2 tahun & \multirow[t]{2}{*}{2 tahun 8 bulan } \\
\hline & & 8 tahun & \\
\hline Penjara lebih 3 tahun & 12 tahun & 16 tahun & 4 tahun \\
\hline Penjara seumur hidup & 18 tahun & $\begin{array}{l}\text { Dlm hal ini tidak } \\
\text { ditentukan tetapi } \\
\text { metunjuk pada } \\
\text { asas bahwa } \\
\text { lamanya tindak } \\
\text { pidana tidak boleh } \\
\text { lebih singkat dari } \\
\text { masa pemidanaan } \\
\text { itu sendiri. Maka } \\
\text { tidak ada daluarsa } \\
\text { untuk klasikasi ini. }\end{array}$ & $\begin{array}{l}\text { Keterangan } \\
\text { bawah tabel }\end{array}$ \\
\hline Pidana mati & & $\begin{array}{l}\text { Tidak ada masa } \\
\text { daluarsa }\end{array}$ & $\begin{array}{ll}\begin{array}{l}\text { Keterangan } \\
\text { bawah tabel }\end{array} & \text { di } \\
\end{array}$ \\
\hline
\end{tabular}


Ketentuan-ketetuan yang diatur dalam Pasal 82 KUHP diuraikan sebagai berikut :

"Pasal 82 ayat 1 , berbunyi :

Hak menuntut hukuman karena pelanggaran yang terancam hukuman utama tidak lain daripada denda, tiada berlaku lagi jika maksimum denda dibayar dengan kemauan sendiridan demikian juga dibayar ongkos perkara, jika penuntutan telah dilakukan, dengan izin amtenar yang ditunjuk dalam undang - undang umum, dalam tempo yang ditetapkannya.

Pasal 82 ayat 2 , berbunyi :

Jika perbuatan itu terancam selainnya denda juga rampasan, maka harus diserahkan juga benda yang patut dirampas itu atau dibayar harganya, yang ditaksir oleh amtenar yang tersebut dalam ayat pertama.

Pasal 82 ayat 3 , berbunyi :

Dalam hal hukuman itu ditambah disebabkan berulang - ulang membuat kesalahan, boleh juga tambahan itu dikenakan, jika hak penuntut hukuman sebab pelanggaran yang dilakukan dahulu telah gugur menurut ayat pertama dan kedua dari pasal itu.

Pasal 82 ayat 4 , berbunyi :

Peraturan dalam pasal ini tidak berlaku bagi orang yang belum dewasa, yang umurnya sebelum melakukan perbuatan itu belum cukup enam belas tahun".

\section{Penyelesaian perkara di luar sidang pengadilan (Pasal 82 KUHP)}

Penyelesaian perkara pidana diluar pengadilan, konsep ini dikenal berdasarkan asas "ius poenaliî" dan "ius poenendi" adalah suatu pemikiran tentang sistem penyelesaian perkara pidana hanya dapat dilakukan melalui lembaga pengadilan. Ketentuan dalam Pasal 82 KUHP bahwa penyelesaian perkara pidana oleh penuntut umum yang tentunya ditijukan kepada tindak pidana yang diancam dengan denda saja, dengan syarat : "a. Jenis tindak pidana adalah pelanggaran, b. Pelanggaran atas tindak pidana ini oleh UU diancam dengan sanksi denda, c. Pelaku berkenan membayar dana maksimum dengan suka rela; d. Jika penuntutan telah dimulai biaya-biaya perkara yang berkaitan dengan pelaksanaan penuntutan dibebankan kepada pelaku, e. Ancaman pidana tambahan berupa peranpasan barang tertentu jika dirumuskan dalam aturan undang-Undang dapat dilaksanakan oleh penuntut umum atau dapat dikonversi kedalam sejumlah uang dengan taksiran yang ditentukan oleh undang-undang, f. Pelaksanaan 
penyelesaian perkara pidana melalui lembaga ini dapat diperhitungkan sebagai pemberatan bila terjadi pengulangan atau recidive." 17

\section{Tabel 3. Pelaksanaan Pidana Denda atau Kurungan}

\begin{tabular}{|l|l|}
\hline $\begin{array}{l}\text { Dalam hal ancaman pidana } \\
\text { adalah denda. }\end{array}$ & $\begin{array}{l}\text { Penuntut umum tidak diperkenankan menolak } \\
\text { bila dengan sukarela pelaku mau membayarkan } \\
\text { denda maksimum dan melaksanakan persyaratan } \\
\text { sebagaimana ditentukan dalam aturan perundang- } \\
\text { undangan. }\end{array}$ \\
\hline $\begin{array}{l}\text { Dalam hal ancaman pidana } \\
\text { adalah denda dan atau } \\
\text { kurungan }\end{array}$ & $\begin{array}{l}\text { Penuntut umum memiliki hak untuk mengabulkan } \\
\text { atau menolak } \\
\text { Bila ia mengabulkan maka ia akan menentukan } \\
\text { syarat dibayarkan sejumlah uang tertentu sebagai } \\
\text { pengganti kurungan yang besarnya minimum 50 } \\
\text { sen dan setinggi-tingginya sama dengan jumlah } \\
\text { denda maksimum. } \\
\text { Penuntut umum juga berwenang menentukan } \\
\text { jangka waktu pelaksanaanya dan tempat dimana } \\
\text { "transaksi" tersebut dilaksanakan. } \\
\text { Adapun bila sampai jangka waktu yang } \\
\text { ditentukan belum dapat dilunasi, maka hal ini } \\
\text { hanya dapat diperpanjang satu kali saja sesuai } \\
\text { dengan jangka waktu yang pertama. }\end{array}$ \\
\hline
\end{tabular}

Simons juga menegaskan bahwa bila terjadi pengulangan atas tindak pidana yang diselesaikan di luar pengadilan ini, maka: ${ }^{18}$

a) Terhadap tindak pidana yang baru, dapat diperberat ancaman pidananya (menjadi dasar recidive); dan

b) Terhadap tindakan pidana yang pertama, dapat dilakukan penuntutan , sehingga penyelesaian dengan cara "transaktie" tersebut tidak diperhitungkan sebagai ne bis in idem.

Alasan gugurnya hak untuk menuntut lainnya yakni : Penyelesaian perkara di luar sidang pengadilan sebagaimana diatur Pasal 82 KUHP, yakni

"Dalam hal terjadi pelanggaran yang diancam denda yaitu membayar kepada kejaksaan maksimum denda yang dikeluarkan untuk perkara, maka si pelaku harus membayar denda dan biaya perkara tersebut dan kalau tidak maka ia bisa dikenakan pidana kurungan sebagai pengganti denda dan biaya perkara tersebut".

\footnotetext{
${ }^{17}$ Eva, Achjani Zulfa, 2013, Gugurnya Hak Menuntut, Dasar Menghapus, Peringan, Pemberat Pidana, cetakan ke dua, Ghalia Indonesia, Bogor, hlm.37

${ }^{18}$ Ibid,
} 
Perbedaan penyelesaian perkara di luar sidang dan di dalam sidang yaitu:

a. Diluar sidang, ongkos/biaya (denda) mahal atau berat, sedangkan di dalam sidang ongkos/biaya (denda) ringan.

b. Diluar sidang, status bukan terhukum, sedangkan di dalam sidang status pernah menjadi terhukum.

Tabel 4. Penyelesain perkara di dalam dan di luar sidang

\begin{tabular}{|l|l|}
\hline \multicolumn{1}{|c|}{ Di dalam sidang } & \multicolumn{1}{c|}{ Di luar sidang } \\
\hline $\begin{array}{l}\text { sidang, ongkos/biaya (denda) mahal } \\
\text { atau berat }\end{array}$ & $\begin{array}{l}\text { sidang, ongkos/biaya (denda) mahal } \\
\text { atau berat }\end{array}$ \\
\hline status pernah menjadi terhukum & status bukan terhukum \\
\hline
\end{tabular}

Hal lain yang gugurnya hak untuk menuntut oleh karena penyelesaian perkara di luar Pengadilan berupa mediasi penal, penyelesaian perkara-perkara yang bersifat delik aduan, disepakati kedua belah pihak dan tidak saling menuntut dikemudian hari.

Pada dasarnya, mediasi di Kepolisian tidak dikenal dalam ketentuan undang-undang mengenai sistem peradilan pidana, yaitu Undang-Undang Nomor 8 Tahun 1981 tentang Hukum Acara Pidana (KUHAP). Dalam Undang-Undang Nomor 2 Tahun 2002 tentang Kepolisian Negara Republik Indonesia (UU Kepolisian) juga tidak diatur mengenai mediasi oleh pihak kepolisian.

Akan tetapi, kita dapat melihat mengenai mediasi oleh polisi dalam tataran di bawah undang-undang, yaitu dalam Surat Kapolri No Pol: B/3022/XII/2009/SDEOPS tanggal 14 Desember 2009 tentang Penanganan Kasus Melalui Alternatif Dispute Resolution (ADR) (Surat Kapolri 8/2009).

Dalam artikel Menakar Keadilan Melalui Penyelesaian Sengketa Pidana di Luar Pengadilan oleh Malik dari Perkumpulan HUMA sebagaimana kami akses dari situs Komite Masyarakat Sipil untuk Pembaharuan KUHAP, disebutkan bahwa dalam Surat Kapolri 8/2009 ditentukan beberapa langkah-langkah penanganan kasus melalui ADR yaitu :

1. Mengupayakan penanganan kasus pidana yang mempunyai kerugian materi kecil, penyelesaiannya dapat diarahkan melalui konsep ADR.

2. Penyelesaian kasus pidana dengan menggunakan ADR harus disepakati oleh pihak-pihak yang berperkara namun apabila tidak terdapat kesepakatan baru diselesaikan sesuai dengan prosedur hukum yang berlaku secara profesional dan proporsional. 
3. Penyelesaian kasus pidana yang menggunakan ADR harus berprinsip pada musyawarah mufakat dan harus diketahui oleh masyarakat sekitar dengan menyertakan RT RW setempat.

4. Penyelesaian kasus pidana dengan menggunakan ADR harus menghormati norma hukum sosial / adat serta memenuhi azas keadilan.

5. Memberdayakan anggota Pemolisian/ Perpolisian Masyarakat (Polmas) dan memerankan Forum Kemitraan Polisi dan Masyarakat (FKPM) yang ada di wilayah masing-masing untuk mampu mengidentifikasi kasus-kasus pidana yang mempunyai kerugian materiil kecil dan memungkinkan untuk diselesaikan melalui konsep ADR.

6. Untuk kasus yang telah dapat diselesaikan melalui konsep ADR agar tidak lagi di sentuh oleh tindakan hukum lain yang kontra produktif dengan tujuan Polmas". ${ }^{19}$

Berdasarkan Surat Kapolri No Pol: B/3022/XII/2009/SDEOPS tanggal 14 Desember 2009 tentang Penanganan Kasus Melalui Alternatif Dispute Resolution (ADR) bisa dikatakan merupakan suatu langkah memotong suatu perkara tertentu tidak sampai pada tahapan penuntutan dan mengurangi kasus-kasus masuk pada Pengadilan. Dengan kebijakan ADR dari Kepolisian ini adalah salah satu bentuk gugurnya hak untuk menuntut, karena perkara telah diselesaikan pada timgkat penyidikan.

\section{Amnesti dan Abolisi dari Presiden (Pasal 14 UUD 1945)}

Amnesti dan Abolisi adalah hak proregatif Presiden yang diberikan oleh Undang-Undang Dasar 1945, tentu saja hak proregatif untuk menghentikan penuntutan suatu perkara pidana secara konstitusi adalah sah, adapun kreteria pemberian amnesti dan abolisi presiden adalah :

a. Amnesti merupakan pencegahan penuntutan atas beberapa orang atau segerombolan orang yang melakukan kesalahan, sedangkan Abolisi merupakan penghentian penuntutan yang sudah berjalan atas seseorang atau beberapa orang yang melakukan kesalahan.

b. Amnesti diberikan sebelum suatu penuntutan mulai dilaksanakan, sedangkan Abolisi diberikan pada saat penuntutan dilakukan.

Perbedaan Amnesti, Abolisi dan Grasi yaitu:

${ }^{19}$ Surat Kapolri No Pol: B/3022/XII/2009/SDEOPS tanggal 14 Desember 2009 tentang Penanganan Kasus Melalui Alternatif Dispute Resolution (ADR) 
a. Amnesti, Abolisi menggugurkan hak untuk menuntut hukuman, sedangkan grasi menggugurkan kewajiban menjalani pidana.

b. Amnesti, Abolisi mencegah/menghentikan penuntutan,sedangkan Grasi menghapus hukuman.

Pasal 14 UUD 1945 , menjelaskan, bahwa :

“(1) Presiden memberi grasi dan rehabilitasi dengan memperhatikan pertimbangan Mahkamah agung. (2) Presiden memberi amnesti dan abolisi dengan memperhatikan pertimbangan Dewan Perwakilan Rakyat."

Amanat konstitusi ini yang diberikan kepada Prisiden ini tidak serta Presiden dapat mengabulkan secara sepihak, tetapi melibat 2 (dua) institusi atau Lembaga Tinggi lainnya, yakni MARI RI dan DPR RI, kedua lembaga ini tinggi negara ini memliki tugas dan fungsi yang berbeda, MARI adalah lembaga dibidang penegakan hukum (justicia), sementara DPR RI bidang kebijakan politik (politic policy). Dengan demikian keputusan tentang amnesti, abolisi dan grasi bukanlah tindakan "otoriter" presiden yang mencampuri urusan hukum yaitu penuntutan.

Presiden, atas kepentingan Negara, dapat memberi amnesti dan abolisi kepada orang-orang yang telah melakukan sesuatu tindakan pidana.

"Presiden memberi amnesti dan abolisi ini setelah mendapat nasihat tertulis dari Mahkamah Agung yang menyampaikan nasihat itu atas permintaan Menteri Kehakiman (saat ini Menteri Hukum dan HAM)" ${ }^{20}$

Berkenaan dengan Amnesti, Abolisi, Grasi dan Rehabilitasi Harus dengan Pertimbangan MA atau DPR, Dahulu sebelum amandemen UUD 1945, grasi, rehabilitasi, abolisi dan amnesti menjadi hak absolut Presiden. Setelah amandemen UUD 1945 pemberian grasi, rehabilitasi, abolisi dan amnesti oleh presiden harus dengan pertimbangan MA atau DPR. Ketentuan tersebut diubah dengan tujuan untuk peningkatan pengawasan terhadap penyelenggaraan pemerintahan oleh Presiden. Dengan adanya ketentuan pertimbangan ini, maka pemberian grasi, rehabilitasi, amnesti, abolisi tidak lagi menjadi hak absolut Presiden, melainkan harus memperhatikan pertimbangan dari MA atau DPR.

Adanya pembatasan kekuasaan Presiden dalam memberikan grasi, rehabilitasi, amnesti, abolisi tersebut sejalan dengan konsep

${ }^{20}$ Pasal 1 Undang-Undang Nomor Tahun 1954 
pemisahan kekuasaan menurut Montesquieu. Menurut Montesquieu sebagaimana dikutip oleh Parlin M. Mangunsong, kemurnian pemisahan kekuasaan negara yang harus dipisahkan menjadi 3 bagian: $^{21}$

1. Kekuasaan Legislatif, yakni pembuat peraturan perundangundangan;

2. Kekuasaan Eksekutif, yakni untuk melaksanakan peraturan perundang-undangan; serta

3. Kekuasaan Yudikatif, yakni untuk mempertahankan peraturan perundang-undangan".

Meskipun pada praktiknya teori pemisahan kekuasaan negara sulit dipertahankan maupun diselenggarakan secara konsekuen, terutama pada negara hukum modern mewajibkan administrasi negara aktif mencampuri kehidupan masyarakat guna mewujudkan dan mempertinggi kesejahteraan umum.

\section{Tidak adanya pengaduan pada delik-delik aduan}

Gugurnya hak untuk menuntut oleh karena tidak adanya pengaduan pada delik-delik aduan. Delik aduan adalah delik yang penuntutannya hanya dilakukan apabila ada pengaduan dari pihak yang terkena atau dirugikan. Menurut sifatnya, delik aduan dibedakan menjadi 2 (dua) yaitu: “"

“(a) Delik aduan yang absolut yaitu delik ini menurut sifatnya hanya dapat dituntut berdasarkan pengaduan. (b) Delik aduan yang relatif, disebut relatif karena dalam delik-delik ini ada hubungan istimewa antara si pembuat dan orang yang dirugikan. Delik bukan aduan adalah tindak pidana yang dapat dituntut tanpa diperlukan adanya suatu pengaduan".

Pada Delik aduan, pengaduan hanya boleh diajukan dalam waktu enam bulan sejak orang yang berhak mengadu mengetahui adanya kejahatan, jika bertempat tinggal di Indonesia, atau dalam waktu sembilan bulan jika bertempat tinggal di luar Indonesia (lihat Pasal 74 ayat [1] KUHP). Dan orang yang mengajukan pengaduan berhak menarik kembali pengaduan tersebut dalam waktu tiga bulan setelah pengaduan diajukan (lihat Pasal 75 KUHP).

${ }^{21}$ S.F Marbun dan kawan-kawan, 2004, .Dimensi-Dimensi Pemikiran Hukum Administrasi Negara, UII Press, Yogyakarta, hlm 40 


\section{B. Sebab-Sebab Gugurnya Hak Untuk Menuntut yang Diatur dalam Kitab Undang-Undang Hukum Pidana (KUHP)}

Sebab-sebab gugurnya hak untuk menuntut bermacam macam, baik secara alami, secara hukum maupun atas perbuatan manusia itu sendiri, sebenarnya gugur hak untuk menuntut dengan telah diatur dalam KUHP dan telah diuraikan satu persatu tentang gugurnya hak untuk menuntut berdasarkan ajaran-ajaran hukum maupun di dalam perundang-undangan, walaupun uraian tentang gugurnya hak untuk menuntut belum secara lengkap Penulis uraiankan disebabkan keterbatasan sumber bahan hukum baik berupa buku maupun perundang-undangan.

Penuntutan adalah tugas dan fungsi Kejaksaan sebagaimana diatur dalam Pasal 2 ayat (1) Undang-Undang 16 Tahun 2004 tentang Kerjaksaan Rebublik Indonesia, menyatakan :

"Kejaksaan Republik Indonesia yang selanjutnya dalam UndangUndang ini disebut kejaksaan adalah lembaga pemerintah yang melaksanakan kekuasaan negara di bidang penuntutan serta kewenangan lain berdasarkan undang-undang".

Sedangkan yang menjadi subjek penuntutan adalah orang-orang yang melakukan tindak pidana dan diperhadapkan di depan sidang pengadilan. Oleh KUHP mengatur kemungkinan-kemungkinan terjadi "kegagalan" untuk menuntut dengan berbagai macam alasan yakni

1. Adanya asas "Ne bis in idem" (Pasal 76 KUHP).

2. Meninggalnya pelaku (Pasal 77 KUHP).

3. Daluwarsa (Pasal 78 KUHP).

4. Penyelesaian perkara di luar sidang pengadilan (Pasal 82 KUHP).

5. Amnesti dan Abolisi dari Presiden (Pasal 14 UUD 1945).

6. Tidak adanya pengaduan pada delik-delik aduan.

Sebab gugurrnya hak menuntut oleh Penulis mengkategorikannya sebagai berikut :

\section{Sebab Alamiah}

Secara alami adalah dikarenakan terdakwanya meninggal dunia, maka tidak dapat tergantikan oleh siapapun, pertanggungjawaban pidana sifatnya perorangan, siapa yang melakukannya dan dapat dimintakan pertanggungjawabnnya maka terdakwa seperti yang dituntut dihadap pengadilan. Dalam unsur delik pemidanaan terdapat unsur "barang siapa" hal diartikan sebagai natuurlijk person, yaitu orang nya sendiri yang melakukan tindakan atau perbuatan pidana. Selain itu terdapat defini tindak pidana yaitu straafbaafeit. 
Jadi istilah Strafbaarfeit adalah peristiwa yang dapat dipidana atau perbuatan yang dapat dipidana.Sedangkan delik dalam bahasa asing disebut delict yang artinya suatu perbuatan yang pelakunya dapat dikenakan hukuman (pidana).Andi Hamzah dalam bukunya Asas-asas Hukum Pidana memberikan definisi mengenai delik, yakni Delik adalah suatu perbuatan atau tindakan yang terlarang dan diancam dengan hukuman oleh undang-undang (pidana).

Kemudian Moeljatno mengartikan Strafbaarfeit itu sebenarnya adalah suatu kelakuan manusia yang diancam pidana oleh peraturan perundang-undangan. Strafbaarfeit juga diartikan oleh Pompe sebagaimana dikutip dari buku karya Lamintang, sebagai Suatu pelanggaran norma (gangguan terhadap tertib hukum) yang dengan sengaja ataupun dengan tidak sengaja telah dilakukan oleh seorang pelaku, dimana penjatuhan hukuman terhadap pelaku tersebut adalah perlu demi terpeliharanya tertib hukum.

Meninggalnya si pelanggar hukum menjadikan penuntutan oleh jaksa penuntut umum menjadi gugur, tinggal bagaimana pelaksanaannya, akan diatur secara teknis oleh penuntut umum yang bersangkutan berdasarkan ketentuan yang ada.

\section{Sebab Perbuatan Manusia}

Seperti halnya diuraikan gugurnya hak untuk menuntut karena daluarsa. Si tersangka ataupun terdakwa melarikan diri, baik pada saat tersangka dalam proses penuntutan, pemeriksaan di pengadilan maupun telah divonis tetapi putusannya belum berkekuatan tetap yang bersangkutan melarikan diri seperti diatur dalam pasal 78 KUHP, maka hal demikian telah ditentukan waktu pelariannya atau tidak ditemukan persembunyian terdakwa maka tidak dapat lahi dituntut.

Selain daluarsa, perkara yang dihadapi tersangka atau terdakwa merupakan delik aduan, pada tahap penyidikan ataupun penuntutan, si korban mencabut pengaduannya, sejak dicabut pengaduan korban tersebut tersangka ataupun terdakwa tidak dapat dituntut, seperti halnya beberapa delik tindak pidana kekerasan dalam rumah tangga (KDRT) menurut Undang-Undang Nomor 23 Tahun 2004, tindak pidana asusila, pasal-pasal: 367, 370, 376, 394, 404, dan 411.

Terdapat juga hapus hak untuk menuntut karena perbuatan manusia yaitu penyelesaian secara kekeluargaan (damai) pada perkara-perkara ringan dalam rangka implementasi restoratif 
justice, oleh karena hal ini memungkinkan dilakukan pada tahap penyidikan berdasarkan Surat Kapolri No Pol: B/3022/XII/2009/SDEOPS tanggal 14 Desember 2009 tentang Penanganan Kasus Melalui Alternatif Dispute Resolution (ADR) bisa dikatakan merupakan suatu langkah memotong suatu perkara tertentu tidak sampai pada tahapan penuntutan dan mengurangi kasus-kasus masuk pada Pengadilan.

\section{Sebab Hukum}

Gugurnya hak untuk menutut disebabkan oleh hukum, seperti halnya adanya asas ne bis idem dimana pelaku tindak pidana tidak dapat dintuntut kedua kalinya oleh karena pelaku (subyek hukumnya) sama dan perkara yang sama telah mendapat putusan/vonis hakim dan telah berkekuatan hukum. selain dari pada itu gugurnya hak untuk menutut karena adanya pengesampingan perkara demi kepentingan hukum (deponir) seperti dijelaskan dalam Undang-Undang Kejaksaan, dan adanya amnesti, abolisi dan grasi dari presiden, seperti diuraikan di atas.

\section{PENUTUP}

\section{A. Kesimpulan}

1. Gugurkannya hak menuntut yang diatur dalam KUHP yaitu terdiri : a) Adanya asas "Ne bis in idem" (Pasal 76 KUHP); b) Meninggalnya pelaku (Pasal 77 KUHP); c) Daluwarsa (Pasal 78 KUHP); d) Penyelesaian perkara di luar sidang pengadilan (Pasal 82 KUHP); e) Amnesti dan Abolisi dari Presiden (Pasal 14 UUD 1945);dan f) Tidak adanya pengaduan pada delik-delik aduan.

2. Penuntut adalah Jaksa Penuntut Umum sebagaimana diatur dalam dalam Pasal 2 ayat (1) Undang-Undang 16 Tahun 2004 tentang Kerjaksaan Rebublik, menyatakan : "Kejaksaan Republik Indonesia yang selanjutnya dalam Undang-Undang ini disebut kejaksaan adalah lembaga pemerintah yang melaksanakan kekuasaan negara di bidang penuntutan serta kewenangan lain berdasarkan undang-undang".

3. Sebab-sebab gugurnya hak untuk menuntut adalah : Sebab alamiah, Sebab perbuatan manusia dan Sebab hukum 


\section{B. Saran}

1. Pada RKUHP yang baru lebih mempertegas alasan-alasan gugurnya hak untuk menuntut, sehingga benar-benar memberikan kepastian hukum bagi masyarakat khususnya tersangka maupun terdakwa.

2. Pada RKUHP yang baru hendaknya perkara-perkara pidana ringan (Tipiring) dapat diselesaikan dengan cara mediasi dengan berbasis keadilan dan memberikan perlindungan hukum kepada korban sehingga tidak semua perkara pidana harus disidangkan ke Pengadilan.

3. Sebaiknya sanksi pidana denda bukan semata masuk ke kas negara, tetapi juga diberikan kepada korban.

\section{DAFTAR PUSTAKA}

\section{Buku}

Amir Ilyas, 2012, Asas-asas Hukum Pidana, Rangkang Education, Yogyakarta.

Cooper, W.W, Yuji, Kohler, 1984, Dictionary for Accountant, Prentice Hall of India, New Delhi.

Eva Achjani Zulfa, 2010, Gugurnya Hak Menuntut, Dasar Penghapus, Peringan, dan Pemberat Pidana, Cetakan Pertama, Ghalia Indonesia.

E.Y. Kanter dan S.R. Sianturi, 2002, Asas-Asas Hukum Pidana di Indonesia dan Penerapannya, Cetakan Ketiga, Storia Grafika, Jakarta.

Hamzah, Andi, 2000, Hukum Acara Pidana Indonesia, PT. Sinar Grafika, Jakarta.

Ismail Sunny, 2000, Mekanisme Demokrasi Pancasila, Varuna, Jakarta.

Kristiana, Yudi, 2006, Independensi Kejaksaan Dalam Penyidikan Korupsi, PT. Citra Aditya Bakti, Bandung.

Lukman Hakim, 2012, Filosofi Kewenangan Organ dan Lembaga Daerah, Setar Press, Malang.

Marwan dan Jimmy, 2009, Kamus Hukum Rangkuman Istilah dan Pengertian Dalam Hukum Internasional, Hukum Pidana, Hukum Perdata, Hukum Islam, Hukum Perburuhan, Hukum Agraria, Hukum Administrasi Negara, Hukum Pajak dan Hukum Lingkungan, Reality Publisher, Surabaya. 
Miriam Budiardjo, 1997, Masalah Accountability dalam Ilmu Politik, Universitas Indonesia, Jakarta.

M.C. Kenchnie, Jean L, 1983, Webster New Universal Unabridged Dictionary, Second Edicition Simon Schulster.

P.A.F. Lamintang, 1997, Dasar-Dasar Untuk Mempelajari Hukum Pidana Yang Berlaku di Indonesia, Cetakan Ketiga, PT. Citra Adiya Bakti. Bandung

S.F Marbun dan kawan-kawan, 2004, .Dimensi-Dimensi Pemikiran Hukum Administrasi Negara, UII Press, Yogyakarta,

Teguh Prasetyo,2012, Hukum Pidana, PT. RajaGrafindo Persada, Jakarta.

Tim Ganeca Sains. 2008. Kamus Lengkap Bahasa Indonesia.Penabur Ilmu, Bandung.

Widodo, 2009, Sistem PemidanaanDdalam Cyber Crime, Laksbang, Yogyakarta.

Wirjono Prodjodikoro dalam Muhammad, Rusli, 2007, Hukum Acara Pidana Kontemporer, PT. Citra Aditya Bakti Bandung

\section{Peraturan Perundang-Undangan}

Undang-Undang Dasar Republik Indonesaia 1945

Kitab Undang-Undang Hukum Pidana (KUHP)

Undang-Undang Nomor 8 Tahun 1981 tentang Kitab Undang-Undang Hukum Acara Pidana (KUHAP)

Undang Nomor 2 Tahun 2002 tentang Kepolisian Negara Republik Indonesia

Undang-Undang 16 Tahun 2004 tentang Kerjaksaan Rebublik Indonesia

Surat Kapolri No Pol: B/3022/XII/2009/SDEOPS tanggal 14 Desember 2009 tentang Penanganan Kasus Melalui Alternatif Dispute Resolution (ADR)

Peraturan Kepala Kepolisian Republik Indonesia Nomor 6 Tahun 2019, tentang Penyidikan Tindak Pidana, keduanya tidak mengeaskan penghentian penyidikan oleh karena tersangka meninggal dunia.

Surat Kapolri No Pol: B/3022/XII/2009/SDEOPS tanggal 14 Desember 2009 tentang Penanganan Kasus Melalui Alternatif Dispute Resolution (ADR) 


\section{Sumber Lain}

https://id.wikipedia.org/wiki/Kitab_Undang-Undang_Hukum_Pidana

https://butew.com/2018/04/10/sebab-sebab-gugurnya-hak-untukmenuntut-dan-menjalani-hukuman-pidana/ 